\title{
Features of electrical conductivity of complex Cu-Mn-ceria-based electrolytes
}

\author{
I. V. Zagaynov ${ }^{\dagger}$ S. V. Fedorov, O. S. Antonova \\ †igorscience@gmail.com
}

A. A. Baikov Institute of Metallurgy and Materials Science, Moscow, 119334, Russia

Fuel cells are the most efficient means to directly convert stored chemical energy to usable electrical energy (an electrochemical reaction). Doped ceria is considered to be a promising electrolyte for operation at intermediate temperatures $\left(500-600^{\circ} \mathrm{C}\right)$. It has been reported that a reduction of ceria can be neglected at this temperature. However, such temperatures are not suitable for singly doped ceria as an electrolyte in a SOFC or other devices due to high electrical resistance. Structural modification of ceria-based solid solutions by co-doping is one of the possible ways to improve their electrical conductivity at this temperature range. In this work, tri-doped ceria based solid electrolyte materials for intermediate temperature solid oxide fuel cell were synthesized by the co-precipitation method with sonication. The materials were characterized via thermogravimetric analysis, X-ray diffraction, scanning electron microscopy, Wagner's polarization technique, and electrochemical impedance spectroscopy. The powders were isostatically pressed at $150 \mathrm{MPa}$ and sintered at $1000^{\circ} \mathrm{C}$ for $4 \mathrm{~h}$ in air to form electrolyte discs for testing. The relative densities of all the samples were more than $90 \%$ after sintering at $1000^{\circ} \mathrm{C}$. The electrical conductivity of these materials was measured by an impedance spectroscopy in the temperature range of $500-750^{\circ} \mathrm{C}$ in air. The conductivity increased with the increasing oxygen vacancies that were induced by charge compensation. It was shown that the $\mathrm{Cu}_{0.08} \mathrm{Mn}_{0.02} \mathrm{Nd}_{0.05} \mathrm{Ce}_{0.85} \mathrm{O}_{2}$ ceramics can become a promising electrolyte.

Keywords: ceria, electrolyte, ionic conductivity.

УДК: 544.6.018.4

\section{Особенности электропроводности сложных электролитов на основе Сu-Mn-диоксид церия}

\author{
Загайнов И.В. ${ }^{\dagger}$ Федоров С. В., Антонова О.С. \\ Институт металлургии и материаловедения имени А. А. Байкова РАН, Москва, 119334, Россия
}

Топливные элементы являются наиболее эффективным средством прямого преобразования накопленной химической энергии в полезную электрическую энергию (электрохимическая реакция). Допированный диоксид церия считается перспективным электролитом для работы в среднетемпературных областях (500-600ㄷ). Показано, что при этой температуре восстановлением диоксида церия можно пренебречь. Однако такие температуры не подходят для однократно допированного диоксида церия в качестве электролита в твердооксидных топливных элементах (ТОТЭ) или других устройствах из-за высокого электрического сопротивления. Структурная модификация твердых растворов на основе диоксида церия путем совместного легирования является одним из возможных способов улучшения их электропроводности в этом диапазоне температур. В данной работе твердые электролитные материалы на основе трехкомпонентного диоксида церия для среднетемпературных твердооксидных топливных элементов (ТОТЭ) были синтезированы методом соосаждения с использованием ультразвукового (УЗ) воздействия. Материалы охарактеризованы с помощью термогравиметрического анализа, дифракции рентгеновских лучей, сканирующей электронной микроскопии, метода поляризации Вагнера и спектроскопии электрохимического импеданса. Порошки изостатически прессовали при 150 МПа и спекали при $1000^{\circ} \mathrm{C}$ в течение 4 ч на воздухе с образованием дисков электролита для испытаний. Относительные плотности всех образцов после спекания при $1000^{\circ} \mathrm{C}$ составили более $90 \%$. Электропроводность этих материалов измерялась методом импедансной спектроскопии в диапазоне температур $500-750^{\circ} \mathrm{C}$ на воздухе. Электропроводность увеличивалась с увеличением кислородных вакансий, вызванных компенсацией заряда. Показано, что керамика $\mathrm{Cu}_{0.08} \mathrm{Mn}_{0.02} \mathrm{Nd}_{0.05} \mathrm{Ce}_{0.85} \mathrm{O}_{2}$ может стать перспективным электролитом.

Ключевые слова: диоксид церия, электролит, ионная проводимость. 


\section{Introduction}

Most attention is paid to the development of electrolytes for intermediate temperature solid oxide fuel cell (IT-SOFC). The properties of the electrolyte have a major impact on fuel cell performance, and this electrolyte should have the following characteristics: high oxide ion conductivity $\left(>10^{-3} \mathrm{~S} / \mathrm{cm}\right)$ and low electronic conductivity; excellent thermal and chemical stability in relation to the reactant environment and the contacting electrode materials; low cost and environmentally benign $[1,2]$. Until now, two routes have been extensively exploited to reduce the ohmic resistance of the electrolyte for SOFC: reduction of the electrolyte thickness and development of new electrolyte materials with higher ionic conductivity at intermediate temperatures [3]. The high operation temperature causes a series of problems including the electrode-electrolyte interface reactions, anode sintering, difficult sealing material selection, and challenging conditions for SOFC assembly. Ceria-based materials with a fluorite structure and oxygen vacancies resulting from the replacement of $\mathrm{Ce}^{4+}$ with trivalent rare-earth ions have been studied extensively as electrolytes for IT-SOFC. Typical systems include gadoliniadoped ceria (GDC) and samaria-doped ceria (SDC), the conductivities of which are remarkably higher than that of YSZ. The potential of co-doping for the enhancement of the ionic conductivity of doped ceria-based electrolytes should be further explored by selecting suitable co-dopants. Thus, it is necessary to investigate ceramics based on ceria solid solutions (using low-cost dopants) as a promising electrolyte. The ionic radius of transition metal cations is much smaller than that of $\mathrm{Ce}^{4+}$, resulting a significant tensile-strained ceria lattice and a decreased oxygen vacancy formation energy [4]. Adding 1-5 mol.\% these oxides into the electrolyte powder could greatly lower the densification temperature and exerts no corruption on the ionic conductivity. The results of studies of the influence on the sintering and the conductivity of GDC of cobalt, copper, manganese, iron, bismuth, samarium, titanium, nickel, and other oxides were obtained. It is shown that the introduction of these additives in the amount of 1-5 mol.\% significantly increases the rate of shrinkage, reduces the sintering temperature, and increases in the total conductivity [5-13]. Co-doped ceria exhibits high ionic conductivity compared to solely doped ceria, because the co-doping process encourages the formation and mobility of oxygen vacancies. Besides, it was reported that some dopants reduced the total ionic conductivity of co-doped solid electrolytes compared to solely doped ceria, owing to the high ionic radius mismatch and hence diminishing the formation of oxygen vacancies [14].

Earlier, a simple and promising electrolyte $\mathrm{Cu}_{0.08} \mathrm{Mn}_{0.02} \mathrm{Ce}_{0.9} \mathrm{O}_{2}$ was proposed [15], which showed good electrical conductivity. This paper will show the effect of additives on the indicated characteristics of the selected electrolyte and possible further improvement.

\section{Material and methods}

Co-doped ceria ceramic powders with different compositions $\left(\mathrm{Cu}_{0.08} \mathrm{Mn}_{0.02} \mathrm{M}_{0.05} \mathrm{Ce}_{0.85} \mathrm{O}_{2}\right.$, where $\left.\mathrm{M}=\mathrm{Sm}, \mathrm{Nd}, \mathrm{Bi}, \mathrm{Ti}, \mathrm{Sn}\right)$ were synthesized by the co-precipitation method. Stoichiometric amounts of precursor salts $\left(\mathrm{Ce}\left(\mathrm{NO}_{3}\right)_{3} \cdot 6 \mathrm{H}_{2} \mathrm{O}, \mathrm{Cu}\left(\mathrm{NO}_{3}\right)_{2} \cdot 3 \mathrm{H}_{2} \mathrm{O}\right.$, $\mathrm{Mn}\left(\mathrm{NO}_{3}\right)_{2} \cdot 4 \mathrm{H}_{2} \mathrm{O}, \mathrm{Nd}\left(\mathrm{NO}_{3}\right)_{3} \cdot 6 \mathrm{H}_{2} \mathrm{O}, \quad \mathrm{SnCl}_{2} \cdot 6 \mathrm{H}_{2} \mathrm{O}, \mathrm{TiCl}_{4}$, $\mathrm{Bi}\left(\mathrm{NO}_{3}\right)_{3} \cdot 5 \mathrm{H}_{2} \mathrm{O}, \mathrm{Sm}\left(\mathrm{NO}_{3}\right)_{3} \cdot 6 \mathrm{H}_{2} \mathrm{O}$, Acros Organics, 99.99) were dissolved in concentrated nitric acid (68\%) with a total salt concentration of $0.667 \mathrm{M}$. After dissolution of salts, this mixture was added to distilled water, giving a concentration of $0.1 \mathrm{M}$. Then, the co-precipitation was carried out by the addition of $2.5 \mathrm{M} \mathrm{KOH}$ solution up to $\mathrm{pH}=11$. Ultrasonic processing $(35 \mathrm{kHz}, 150 \mathrm{~W})$ was used during the entire process at $30^{\circ} \mathrm{C}$ under stirring. The resulting precipitates were filtered, washed with distilled water-ethanol solution (volume ratio of $\mathrm{H}_{2} \mathrm{O} / \mathrm{C}_{2} \mathrm{H}_{5} \mathrm{OH}=9$ ), dried at $150^{\circ} \mathrm{C}$ for $12 \mathrm{~h}$ and calcined in static air by heating at a rate of $4^{\circ} \mathrm{C} / \mathrm{min}$ from room temperature to $500^{\circ} \mathrm{C}$ and kept at $500^{\circ} \mathrm{C}$ for $1 \mathrm{~h}$ in a muffle furnace $[16,17]$.

The as-obtained powders were pressed into pellets (with $10 \mathrm{wt} . \%$ binder made of $5 \mathrm{wt} . \%$ aqueous solution of polyvinyl alcohol) with a diameter of $10 \mathrm{~mm}$ a thickness of $1 \mathrm{~mm}$ at $150 \mathrm{MPa}$. The pressed pellets were sintered at $1000^{\circ} \mathrm{C}$ for $4 \mathrm{~h}$ in air with a heating rate of $4^{\circ} \mathrm{C} / \mathrm{min}$.

All powders and ceramics were characterized by XRD (DRON-3M, $\mathrm{Cu}_{\mathrm{Ka}}$-radiation). Thermal analyses were performed using TG-DTA (Netzsch STA449F3) and the samples were heated to $1300^{\circ} \mathrm{C}$ at a rate of $10^{\circ} \mathrm{C} / \mathrm{min}$ in air. The microstructure of the sintered samples was investigated using SEM-EDS (TESCAN VEGA II SBU with INCA Energy 300 energy dispersive spectrometers). The relative density of each sintered sample was determined by the Archimedes method.

Symmetric cells for the impedance studies (Elins Z-350M impedance meter, the frequency range from $0.1 \mathrm{~Hz}$ to $4 \mathrm{MHz}$ at the amplitude of AC signal of $30 \mathrm{mV}$ ) were prepared by deposition (brushing) of platinum paste onto both sides of the electrolyte pellets, drying at $150^{\circ} \mathrm{C}$ for $1 \mathrm{~h}$ and annealing at $900^{\circ} \mathrm{C}$ for $4 \mathrm{~h}$ in air. A platinum wire was used as a current collector. To separate the ionic contribution from the total conductivity, the Wagner's polarization technique with an electrical loader (Solartron 1285A Potentiostat) was used to calculate the ionic transport number by imposing an external fixed DC voltage $(1.5 \mathrm{~V})$ across the electrolyte (DC current was monitored as a function of time by applying a fixed DC voltage across the symmetric C $\mid$ electrolyte $\mid \mathrm{C}$ cell). The evidence of the adequacy of the selected models and the accuracy of the modeling were included in supplementary material.

\section{Results and Discussion}

The designation of the samples and their main characteristics are presented in Table 1 (the numbers of the samples in the table and in the figures correspond to each other). Fig. 1a shows the XRD spectra of powders where a single fluorite phase of ceria was detected that confirms the complete dissolution of dopants into the ceria lattice and also the purity of the final products. There are obvious deviations in the diffraction peak positions, indicating the formation of a solid solution. The thermal stability of solid solutions in air was estimated by the TG-DTA method (Fig. S1, supplementary material). The endothermic peak at $1050-1300^{\circ} \mathrm{C}$ is associated with the formation of additional phases. XRD 
Table 1. Some characteristics of samples: powders $\left(T_{\text {calc }}=500^{\circ} \mathrm{C}\right)$ and ceramics $\left(T_{\text {sint }}=1000^{\circ} \mathrm{C}\right)$.

\begin{tabular}{|c|c|c|c|c|c|c|c|}
\hline No. & Sample & $\begin{array}{c}d_{\text {XRD }}, \mathrm{nm} \\
\text { (powder) }\end{array}$ & $\begin{array}{c}a, \mathrm{~nm} \\
\text { (powder) }\end{array}$ & $\begin{array}{c}a, \mathrm{~nm} \\
\text { (ceramics) }\end{array}$ & $E_{a}, \mathrm{eV}$ & $\begin{array}{c}\sigma_{600^{\circ} \mathrm{C}} \\
10^{-3} \mathrm{~S} / \mathrm{cm}\end{array}$ & $\begin{array}{c}\text { Relative } \\
\text { density, \% }\end{array}$ \\
\hline 1 & $\mathrm{Cu}_{0.08} \mathrm{Mn}_{0.02} \mathrm{Ce}_{0.9} \mathrm{O}_{2}$ & 9 & 5.4064 & 5.4092 & 0.63 & 1.61 & 93 \\
\hline 2 & $\mathrm{Cu}_{0.08} \mathrm{Mn}_{0.02} \mathrm{Sm}_{0.05} \mathrm{Ce}_{0.85} \mathrm{O}_{2}$ & 10 & 5.4078 & 5.4093 & 1.62 & 0.12 & 96 \\
\hline 3 & $\mathrm{Cu}_{0.08} \mathrm{Mn}_{0.02} \mathrm{Nd}_{0.05} \mathrm{Ce}_{0.85} \mathrm{O}_{2}$ & 8 & 5.4156 & 5.4174 & 1.33 & 1.19 & 89 \\
\hline 4 & $\mathrm{Cu}_{0.08} \mathrm{Mn}_{0.02} \mathrm{Bi}_{0.05} \mathrm{Ce}_{0.85} \mathrm{O}_{2}$ & 8 & 5.4130 & 5.4102 & 1.01 & 0.04 & 94 \\
\hline 5 & $\mathrm{Cu}_{0.08} \mathrm{Mn}_{0.02} \mathrm{Ti}_{0.05} \mathrm{Ce}_{0.85} \mathrm{O}_{2}$ & 7 & 5.4005 & 5.4092 & 0.75 & 0.09 & 94 \\
\hline 6 & $\mathrm{Cu}_{0.08} \mathrm{Mn}_{0.02} \mathrm{Sn}_{0.05} \mathrm{Ce}_{0.85} \mathrm{O}_{2}$ & 7 & 5.3991 & 5.4087 & 1.01 & 0.04 & 94 \\
\hline
\end{tabular}

* sample numbers in the table and in the figures correspond to each other

pattern of the calcined powders at $1300^{\circ} \mathrm{C}$ (Fig. 1b) shows that both phases of the ceria solid solution and other phases were formed. All peaks reflect the typical fluorite structure of ceria. In all samples, there is a phase of $\mathrm{CuO}$. Initial system 1 has only this phase, in turn, the spinel $\mathrm{Cu}_{1.5} \mathrm{Mn}_{1.5} \mathrm{O}_{4}$ is formed in system 2, indicating that samarium "extrudes" copper and manganese out of the ceria lattice; while other dopants form with copper or manganese the corresponding phases shown in the figure. In general, the addition of a third dopant, leading to a complication of the solid solution, reduces the stability of the solid solution (the appearance of additional phases shifts from 1250 to $1050^{\circ} \mathrm{C}$ ). Therefore, based on this, a sintering temperature of $1000^{\circ} \mathrm{C}$ is selected (Fig. S2, supplementary material). The relative density of the ceramic obtained at this temperature calculated as the ratio of the densities determined by hydrostatic weighing and by XRD data on the basis of cell parameters was more than $90 \%$ (Table 1). The formation of an additional phase and its melting at higher temperature range $\left(>1300^{\circ} \mathrm{C}\right)$ leads to densification. The ceria grain was covered by a solidified melted phase [18].

Scanning electron microscopy (SEM) analysis of a sample plays a vital role in the investigation of surface morphologies. The sintered doped ceria pellet was sputtered with gold coating in order to enable the SEM characterization. After sintering at $1000^{\circ} \mathrm{C}$ for 4 hours, all the sintered samples were composed of nearly fully dense structures and had a uniform structure (Fig. 2). This is in good agreement with the relative density of the samples. The mean grain size was found to be $1 \mu \mathrm{m}$ according to the SEM results. All samples prepared from the synthesized powders had good sinterability and relatively uniform grain size distribution. In samples 1,2 , and 4, the intercrystalline fracture was observed, and in 3, 5 and 6, it was transcrystalline. Energy dispersive spectroscope characterization was used to study the elemental distribution of all the compositions and presence as well as the percentage of elements within the compositions. The sintering approaches influence the final ceramics properties, so for this goal EDS analysis was used to characterize the stability of the chemical composition being described by the following formulas: $1-\mathrm{Cu}_{0.083} \mathrm{Mn}_{0.023} \mathrm{Ce}_{0.894} \mathrm{O}_{2}, 2-\mathrm{Cu}_{0.072} \mathrm{Mn}_{0.025} \mathrm{Sm}_{0.042} \mathrm{Ce}_{0.861} \mathrm{O}_{2}$, $3-\mathrm{Cu}_{0.060} \mathrm{Mn}_{0.040} \mathrm{Nd}_{0.070} \mathrm{Ce}_{0.830} \mathrm{O}_{2}, 4-\mathrm{Cu}_{0.071} \mathrm{Mn}_{0.024} \mathrm{Bi}_{0.056} \mathrm{Ce}_{0.849} \mathrm{O}_{2}$, $5-\mathrm{Cu}_{0.089} \mathrm{Mn}_{0.028} \mathrm{Ti}_{0.047} \mathrm{Ce}_{0.836} \mathrm{O}_{2}, 6-\mathrm{Cu}_{0.078} \mathrm{Mn}_{0.022} \mathrm{Sn}_{0.044} \mathrm{Ce}_{0.856} \mathrm{O}_{2}$. In this study, the conductivity of the samples was calculated from their resistances obtained by the $\mathrm{AC}$ impedance measurements (Fig. 3). The conductivity without adding any dopants is higher, which is apparently associated

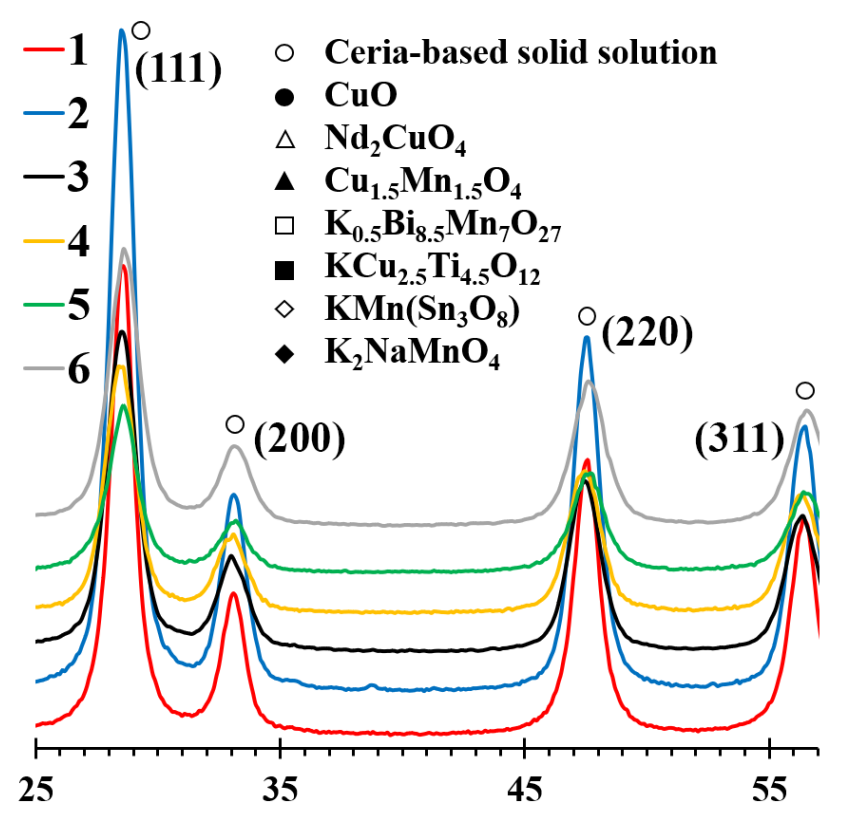

a

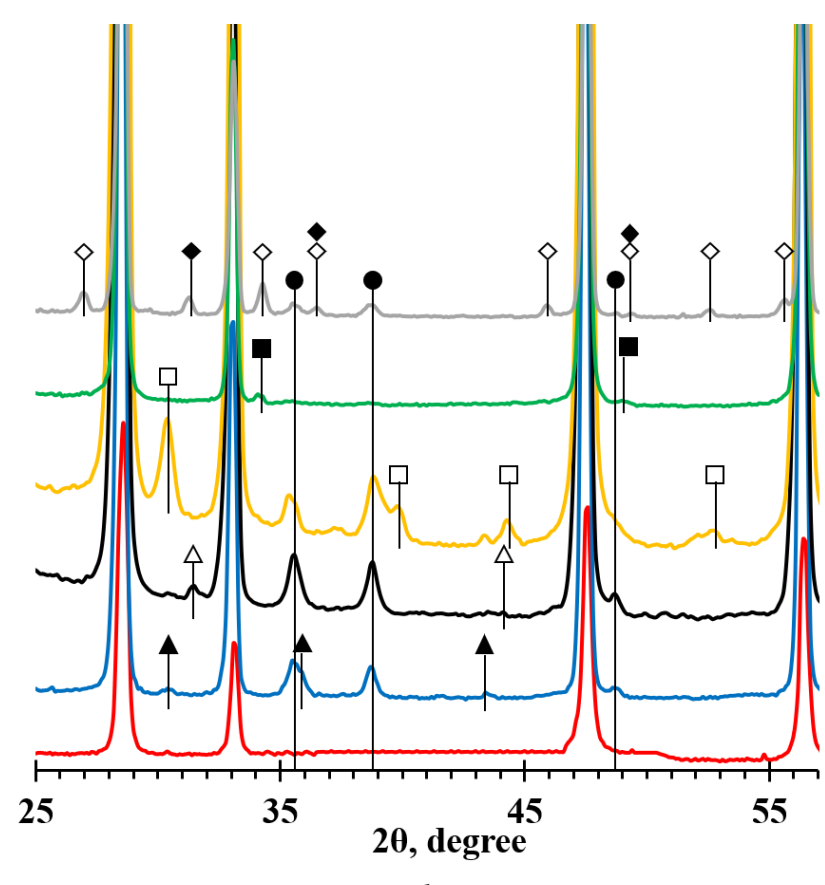

b

Fig. 1. (Color online) XRD patterns of powders calcined at 500 (top figure) and $1300^{\circ} \mathrm{C}$ (bottom figure). 


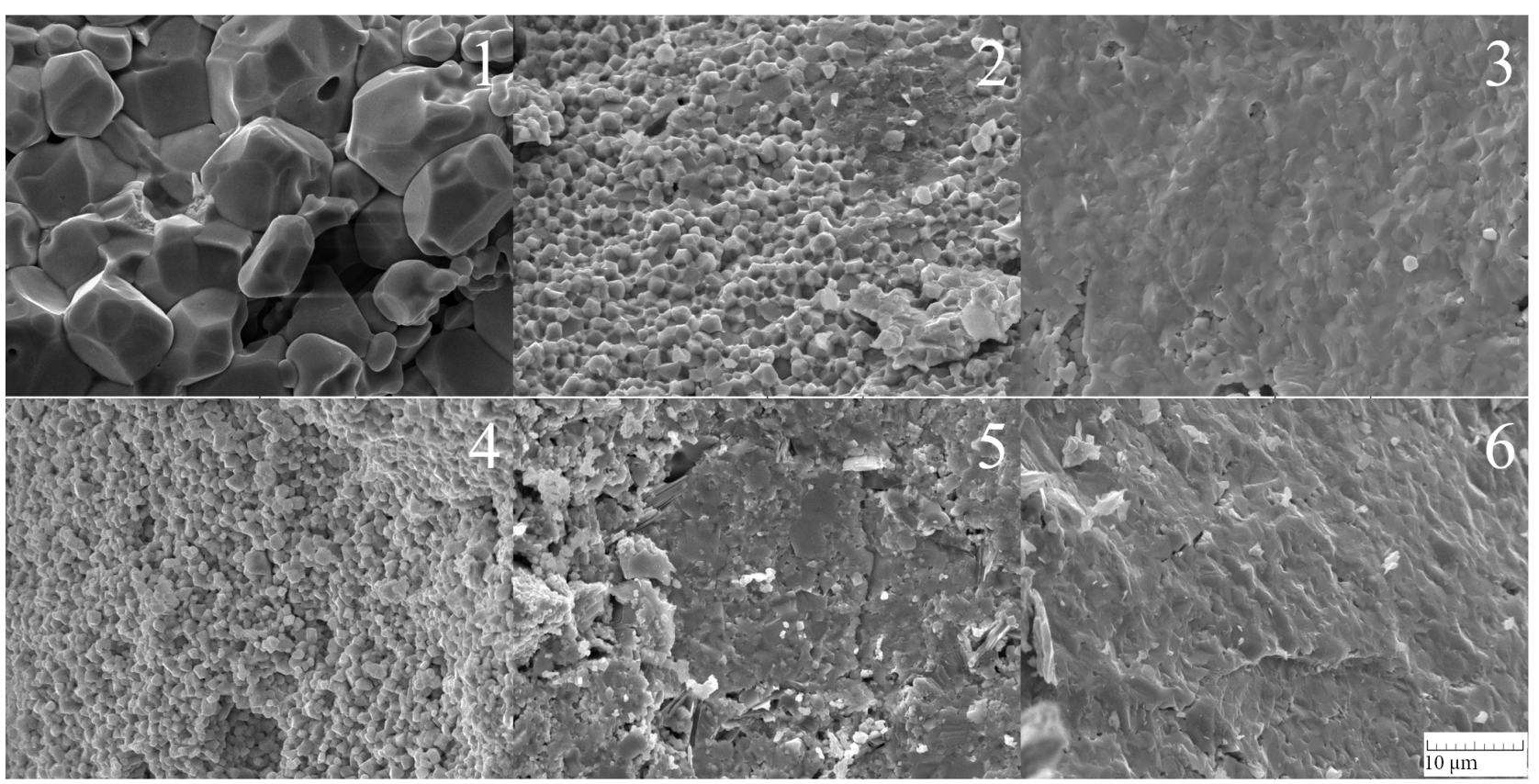

Fig. 2. SEM images of cross-sectional fracture surfaces of ceramics (cleavage, scale bar $10 \mu \mathrm{m}$ ).

with low activation energies (Table 1, using the ArrheniusFrenkel relation), however, as the temperature rises, the conductivity of samples 2 and 3 begins to increase rapidly, and at a temperature of $670-700^{\circ} \mathrm{C}$ it already exceeds. The conductivity of the electrolyte is related to the relative density, grain size, and oxygen vacancy concentration [19]. The higher the relative density of the electrolyte, the greater the conductivity. It is possible that asymmetric voids may alter the transport properties of oxygen ions and thus reduce the conductivity. For the electrolyte samples studied here, the relative density is almost the same, so we ignored the influence of the relative density on the conductivity. The influence of the grain size on electrical conductivity is mainly determined by grain resistance and grain boundary resistance. When the grain size is too large and is accompanied by non-uniform growth, a large number of lattice mismatches is generated in the grain, thus preventing the movement of oxygen ions (that is, the grain resistance increases) and reducing the conductivity; when the grain size is small, the grain boundary resistance will increase, thereby reducing the conductivity. However, this parameter can be ignored as the grain size is almost uniform and the same for all samples. It may be attributed to the increase in the defect interactions, which consequently reduce the mobile oxygen vacancy concentration, but, as mentioned, with increasing temperature the conductivities are higher than that of sample 1 [6]. Increasing the dopant concentration initially enhances the ionic conductivity. However, at a certain doping level, the conductivity reaches its maximum value and then decreases due to the low mobility of defect associates. The extent of formation of these associates increases with the increasing ionic-radii mismatch of dopant cations with respect to the host cation.

The ionic conductivity is related to the number of oxygen vacancies and the oxide ion mobility. Pure ceria is a poor oxide ion conductor. However, doping it with trivalent or divalent dopant cations introduces oxygen vacancies $\left(\mathrm{V}_{\mathrm{O}} ..\right)$

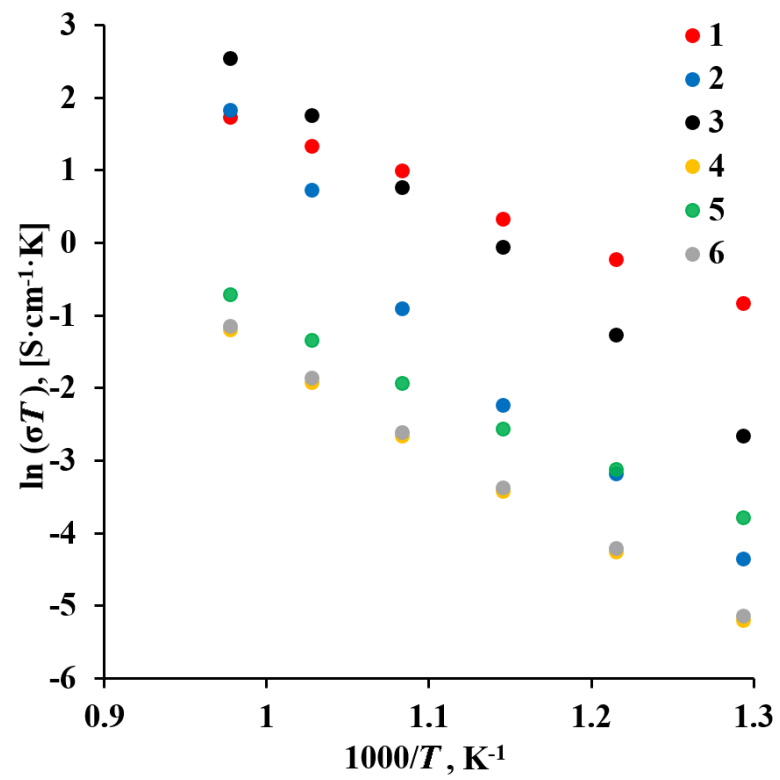

Fig. 3. (Color online) The Arrhenius total conductivity plots of the doped ceria ceramics.

in the ceria lattice as charge compensating defects, which increase the ionic conductivity. The study has shown that doped ceria-based electrolytes exhibit electronic conductivity mainly at high temperatures $\left(>900^{\circ} \mathrm{C}\right)$. Moreover, the oxide ion transference number of co-doped ceria electrolytes was estimated. For samples 1, 5, 6 this value at $600^{\circ} \mathrm{C}$ was $0.86-0.87$, for samples 2,3 it was 0.94 , and for sample 4 it was about 0.98 . Thus, the increased conductivity of sample 1 is associated with a larger fraction of the electronic component, rather than the oxygen ionic conductivity, which is necessary in electrolytes. When compared with other electrolytes, sintered even at a higher temperature, the electrical conductivity of the developed systems is comparable with samples doped by $\mathrm{REE}[20-22]$ at $600^{\circ} \mathrm{C}$. However as known, $\mathrm{CuO}$ can form 
a ceria-CuO in the grain boundary. This phase, can melt at a definite temperature and promote liquid phase sintering. As a consequence, dense bodies can be formed quickly due to the diffusion of liquid phase under capillary action, along with grain rearrangement with an effect on the total conductivity, thus creating only a REE-ceria solid solution as an electrolyte [23]. The comprehensive data on the effects on the electronic and grain boundary transport characteristics will ameliorate the prediction of the effect of interdiffusion of metal cations in complex ceria-based systems. In the future, the effect of different transition metal cations could possibly be exploited to improve the performance of ceria-based materials by deliberately choosing a metal, depending on the required characteristics of a ceria-based compound (high oxygen ion conductivity, high mixed conductivity, etc.).

The impedance graph of the sintered sample at a temperature of $600^{\circ} \mathrm{C}$ is shown in Fig. 4 (and Fig. S3, supplementary material). Generally, impedance spectra consist of graphs with real part $Z^{\prime}$ on the $x$-axis and negative imaginary part $Z^{\prime \prime}$ on the $y$-axis known as complex impedance spectra. The complex impedance plot (Nyquist plot) of an electrolyte material is generally characterized by three successive semicircles: grain (bulk) (higher frequency), grain boundary (moderate frequency), and electrode (lower frequency) contributions. This figure reveals the presence of three or uncompleted semicircle for different samples, which corresponds to the contribution of the grain, grain boundary, and electrode polarization, respectively. There is no semicircle of the grain interior at high frequencies due to the limitation of the frequency range of the test equipment (from $0.1 \mathrm{~Hz}$ to $4 \mathrm{MHz}$ ). The total impedances decreased with increasing temperature and shifted to a higher frequency (at temperatures of $500-750^{\circ} \mathrm{C}$ ). In some samples, the contributions of bulk resistance $\left(R_{g}\right)$ and grain boundary resistance $\left(R_{g b}\right)$ were not well resolved due to their similar relaxation times of charge carriers both in the bulk and at grain boundaries $[24,25]$.

\section{Conclusions}

The doped ceria electrolytes were successfully prepared by a simple co-precipitation method and sintered at a low temperature of $1000^{\circ} \mathrm{C}$ for $4 \mathrm{~h}$ in air. In this study, all samples had cubic fluorite phases and no secondary phase was observed in the XRD analysis. It has been shown that using tri-doped ceria can increase oxygen vacancies, therefore, demonstrate an increase in the oxygen ionic conductivity of the material. Overall results indicate that co-doped ceria sintered at a temperature of $1000^{\circ} \mathrm{C}$ and below is a promising material for application as solid oxide fuel cell electrolyte.

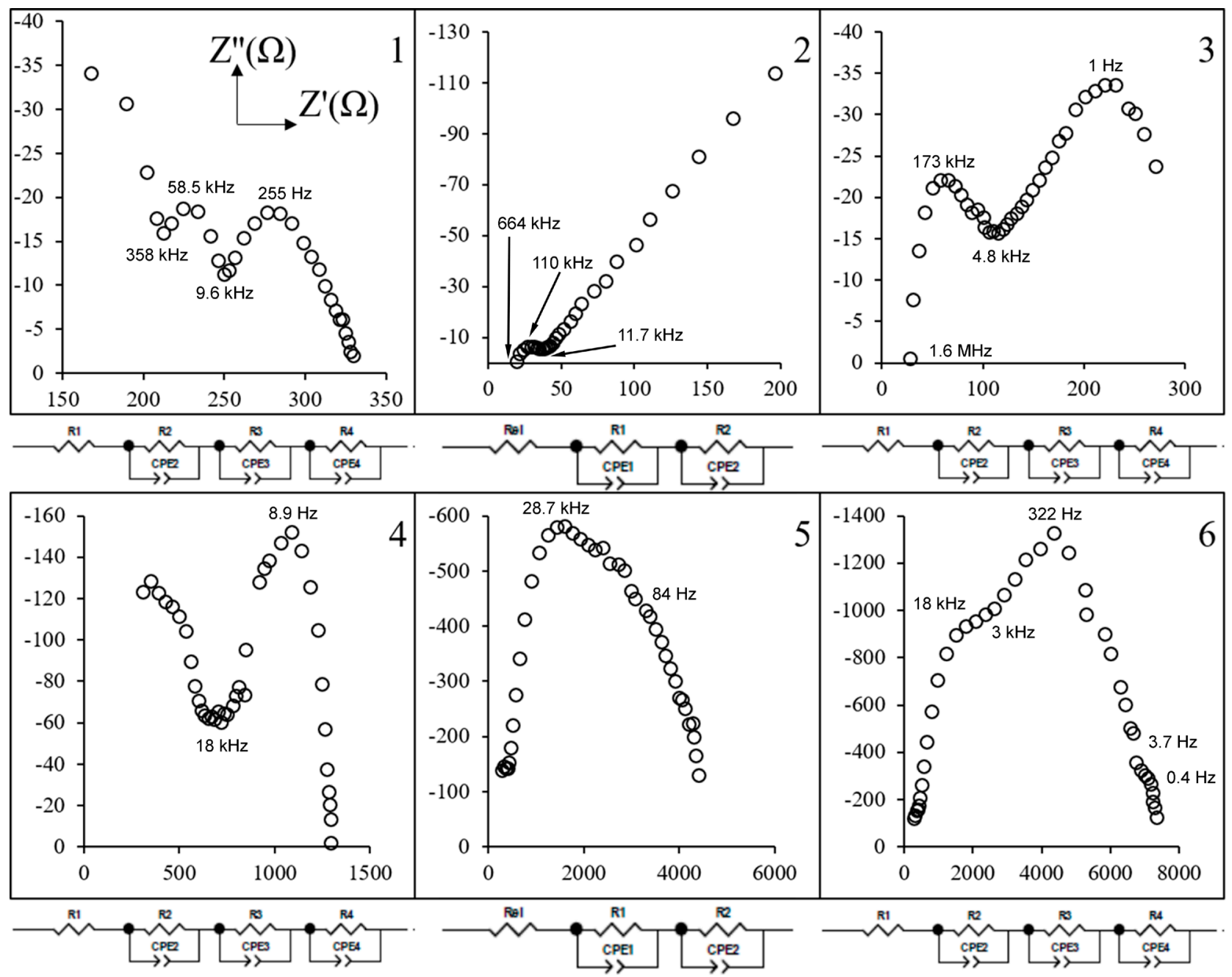

Fig. 4. Complex impedance spectra of samples at $600^{\circ} \mathrm{C}$ in air with equivalent circuits. 
Supplementary material. The online version of this paper contains supplementary material available free of charge at the journal's Web site (lettersonmaterials.com).

\section{References}

1. D. J. L. Brett, A. Atkinson, N. P. Brandon, S. J. Skinnerd. Chem.Soc. Rev. 37, 1568 (2008). Crossref

2. J. B. Goodenough. Annu. Rev. Mater. Res. 33, 91 (2003). Crossref

3. Z. Shao, M.O. Tadé. Intermediate-Temperature Solid Oxide Fuel Cells: Materials and Applications. Springer (2016) 266 p. Crossref

4. Y.-Q. Su, L. Zhang, V. Muravev, E.J. M. Hensen. Chinese J. Catal. 41, 977 (2020). Crossref

5. C. Zhang, J. Sunarso, Z. Zhu, S. Wang, S. Liu. Solid State Ionics. 310, 121 (2017). Crossref

6. A. Arabaci. Mater. Sci. Eng. B. 260, 114646 (2020). Crossref

7. Y. Dong, S. Hampshire, J. Zhou, X. Dong, B. Lin, G. Meng, J. Eur. Ceram. Soc. 31, 2365 (2011). Crossref

8. E. Yu. Pikalova, A.N. Demina, A.K. Demin, A. A. Murashkina, V.E. Sopernikov, N. O. Esina. Inorg. Mater. 43, 735 (2007). Crossref

9. A. Arabaci. Metall. Mater. Trans. A Phys. Metall. Mater. Sci. 48, 2282 (2017). Crossref

10. X. Chen, X. Sun, J. Zhou, D. Zhou, X. Zhu, J. Meng. Ceram. Int. 46, 22727 (2020). Crossref

11. J. Myung, T.H. Shin, X. Huang, G. Carins, J. T. S. Irvine. Int. J. Hydrogen Energ. 40, 12003 (2015). Crossref
12. G. Accardo, J. K. Bae, S. P. Yoon. Appl. Sci. 10, 4573 (2020). Crossref

13. S. Xu, J. Liu, K. Li, Y. Zhou, D. Xu. J. Alloy. Compd. 780, 711 (2019). Crossref

14. A. K. Devi, G. Ram kumar, C. Prerna, K.A. Bhabu, C. Daniel, V. Sabarinathan, T.R. Rajasekaran. JOM (2021). Crossref

15. I. V. Zagaynov, S. V. Fedorov, M.A. Goldberg. Process. Appl. Ceram. 13, 244 (2019). Crossref

16. I. V. Zagaynov, A. A. Konovalov, E. A. Koneva. Lett. Mater. 8 (2), 135 (2018). Crossref

17. I. V. Zagaynov, A. V. Naumkin, Yu. V. Grigoriev. Appl. Cat. B. 236, 171 (2018). Crossref

18. Z. Zhang, W. Sigle, M. Rühle, E. Jud, L. J. Gauckler. Acta Mater. 55, 2907 (2007). Crossref

19. Y. Xue, S. An, S. Li, J. Peng, C. Cai, Y. Liu. J. Solid State Electrochem. 24, 1639 (2020). Crossref

20. N. Tian, Y. Qu, H. Men, J. Yu, X. Wang, J. Zheng. Solid State Ionics. 351, 115331 (2020). Crossref

21. J. Koettgen, M. Martin. Am. Ceram. Soc. 103, 3776 (2020). Crossref

22. N. Jaiswal, K. Tanwar, R. Suman, D. Kumar, S. Upadhyay, O. Parkash. J. Alloy. Compd. 781, 984 (2019). Crossref

23. K. Neuhaus, R. Dolle, H.-D. Wiemhöfer. J. Electrochem. Soc. 167, 044507 (2020). Crossref

24. Y.-C. Wu, C.-C. Lin. Int. J. Hydrogen Energ. 39, 7988 (2014). Crossref

25. I. V. Zagaynov, S.V. Fedorov, A.A. Konovalov, O. S. Antonova. Mater. Lett. 203, 9 (2017). Crossref 